\title{
Blood antioxidant nutrients in riparian villagers of the Brazilian Amazon: its associations with wet/dry seasons and modulation by sociodemographic determinants
}

\author{
Antioxidantes sanguíneos provenientes da dieta em \\ ribeirinhos da Amazônia Brasileira: suas relações com \\ sazonalidade e determinantes sociodemográficos
}

\author{
Juliana Valentini ${ }^{1}$, Carlos José Sousa Passos², Solange Cristina Garcia ${ }^{3}$, \\ Robert Davidson ${ }^{4}$, Marc Lucotte ${ }^{5}$, Frédéric Mertens ${ }^{6}$, Christine Romana ${ }^{7}$, \\ Lígia Meres Valadão ${ }^{1}$, Mariele Feiffer Charão³, Marília Baierle ${ }^{3}$, \\ Fernando Barbosa Júnior ${ }^{8}$
}

\begin{abstract}
This study associates blood antioxidants like copper $(\mathrm{Cu})$, manganese $(\mathrm{Mn})$, selenium $(\mathrm{Se})$, zinc $(\mathrm{Zn})$, $\beta$-carotene, lycopene and vitamins ( $A$ and $E$ ) to sociodemographic features and seasonality in communities from the Tapajós River region, Brazilian Amazon. We observed increased Mn, Se and $\mathrm{Zn}$ levels compared to the average Brazilian population, whereas this is only the case for $\beta$-carotene in the rainy season. Lycopene levels fall within the reference range, although lower than those found in other Brazilian regions. $\mathrm{Cu}, \mathrm{Se}, \mathrm{Zn}, \beta$-carotene, lycopene and vitamin $\mathrm{E}$ levels vary among seasons. $\beta$-carotene, Mn and Se vary among communities. Se and $\mathrm{Zn}$ vary with smoking habits and sex, respectively. In addition, $\beta$-carotene and vitamins $(A$ and $E)$ are altered by alcohol consumption. Villagers who both farmed and fished present higher $\mathrm{Cu}$ and lower $\beta$-carotene levels than participants with a single occupation. Vitamin E levels depend upon the individual state of origin. These data provide important baseline information for antioxidant status in this Amazonian riparian population.
\end{abstract}

Keywords: carotenoids; vitamins; metals; Amazon.

${ }^{1} \mathrm{PhD}$. Instituto de Saúde Coletiva, Universidade Federal do Oeste do Pará (UFOPA) - Santarém (PA), Brazil.

${ }^{2}$ PhD. Faculdade de Planaltina, Universidade de Brasília (UnB) - Planaltina (DF), Brazil.

${ }^{3}$ PhD. Laboratório de Toxicologia (LATOX), Faculdade de Farmácia, Universidade Federal do Rio Grande do Sul (UFRGS) - Porto Alegre (RS), Brazil.

${ }^{4} \mathrm{PhD}$. Collection Vivante et Recherche, Biodôme de Montréal - Montréal (Québec), Canadá.

${ }^{5} \mathrm{PhD}$. Université du Québec à Montréal - Montréal (Québec), Canadá.

${ }^{6} \mathrm{PhD}$. Centro de Desenvolvimento Sustentável (CDS), Universidade de Brasília (UnB) - Brasília (DF), Brazil.

${ }^{7} \mathrm{PhD}$. Institut de Recherche pour le Développement, Université Paris Descartes-PRES Paris Cité Sorbonne - Paris, France.

${ }^{8} \mathrm{PhD}$. Laboratório de Toxicologia e Essencialidade de Metais, Faculdade de Ciências Farmacêuticas de Ribeirão Preto (FCFRP), Universidade de São Paulo (USP)

- Ribeirão Preto (SP), Brazil.

Study carried out at Tapajos River region, State of Pará (Brazilian Amazon), 2010-2011, Santarem (PA), Brazil.

Correspondence: Juliana Valentini - Avenida Mendonça Furtado, 2946 - Fátima - CEP: 68040-470 - Santarém (PA), Brazil -

Email: valentinijuliana@gmail.com

Financial support: Canadian Institutes of Health Research, Canadian International Development Agency, Global Health Research Initiative (GHRI), Public Health Agency of Canada. Its agencies and Brazil and its agencies signed a according being the numbers: IDRC (103460-049) and Foundation for the State of São Paulo Research (11/07797-6).

Conflict of interests: nothing to declare. 


\begin{abstract}
Resumo
O presente estudo reporta as concentrações plasmáticas dos antioxidantes cobre $(\mathrm{Cu})$, manganês (Mn), selênio (Se), zinco (Zn), $\beta$-caroteno, licopeno e vitaminas ( $\mathrm{A}$ e E) em moradores da região do Rio Tapajós, Pará, Amazônia, e as relaciona com características sociodemográficas e sazonalidade (seca e cheia). Os teores de $\mathrm{Mn}$, Se e Zn foram acima dos valores de referência (VR) e daqueles achados em outras regiões do Brasil, enquanto para o $\beta$-caroteno tal achado ocorreu apenas na estação da cheia. Os valores de licopeno foram dentro dos VR, porém abaixo dos achados em outras regiões do Brasil. Os níveis de Cu, $\mathrm{Se}, \mathrm{Zn}, \beta$-caroteno, licopeno e vitamina $\mathrm{E}$ variaram entre as estações. Variação intercomunitária foi constatada para $\beta$-caroteno, $\mathrm{Mn}$ e Se. Os teores de Se e Zn foram alterados, respectivamente, por tabagismo e sexo. Os níveis de $\beta$-caroteno e vitaminas ( $A$ e E) alteraram-se com o consumo de bebida alcoólica. A vitamina $E$ foi dependente do estado de origem. Participantes que desempenhavam ambas as profissões de agricultor e pescador apresentavam teores de Cu superiores e de $\beta$-caroteno inferiores comparativamente àqueles que desempenhavam uma única profissão. Esses dados fornecem informações sobre os teores de antioxidantes para essa população amazônica.
\end{abstract}

Palavras-chave: carotenoides; vitaminas; metais; Amazônia

\section{INTRODUCTION}

Amazonian riparian populations diet depend upon fish, fruits and vegetable $^{1-3}$. Due to mercury $(\mathrm{Hg})$ environmental contamination resulting from gold mining and/or slash-and-burn agriculture, the dietary human exposure to $\mathrm{Hg}$ through consumption of contaminated fish has been the subject of much concern in this region over the last decades ${ }^{4-7}$, and recent studies have indicated that food other than fish, such as tropical fruits may influence the relationship between fish consumption and $\mathrm{Hg}$ exposure, potentially providing protective effects against health toxic effects in riparian communities, ${ }^{2,68-10}$. For instance, the serum carotenoid profile may be considered a good biomarker of fruit and vegetable intake ${ }^{11}$. Additionally, the consumption of other types of food such as vegetables, cereals, meat, and fish itself may directly affect the levels of important micronutrients such as vitamins and essential metals in the bloodstream ${ }^{3,12}$.

Population sociodemographic and lifestyle features such as sex, age, body mass index (BMI), smoking habits, alcohol consumption, the presence of pathologies, among other variables, may also affect blood levels of essential metals and vitamins ${ }^{13-15}$. Yet, few studies have evaluated blood levels of important micronutrients of Amazonian riparian populations ${ }^{3,14,16}$. In addition, while the wet/dry seasons cycle in this region profoundly influences the types of foods consumed throughout the year ${ }^{1}$, its influence on blood micronutrient levels has not yet been taken into consideration. To our knowledge, blood levels of carotenoids and vitamins in this population have never been reported, which makes it important to establish reference ranges for this specific population, since these ranges may differ from those established for other geographic regions, due to dissimilar environmental conditions and lifestyles, which ultimately can lead to different benefits and/or risks to human health.

This study was conducted with small-scale subsistence agriculture and fish-eating villagers of the Tapajós River region, during two different seasons (rainy and dry seasons). The purpose was twofold: a) evaluate the seasonal blood variation of essential metals ( $\mathrm{Cu}, \mathrm{Mn}$, Se and $\mathrm{Zn}$ ), carotenoids ( $\beta$-carotene and lycopene) and vitamins (A and $\mathrm{E}) ; \mathrm{b}$ ) analyse the nutritional status for these micronutrients with respect to the influence of seasonality, sociodemographic and lifestyle factors.

\section{METHODS}

\section{Study population}

The individuals enrolled in this study were from different communities located in the middle Tapajós River region, State of Pará (Brazilian Amazon), namely Lago Araipa (LA), Nova Estrela (NE) and São Tomé (ST) (Figure 1). These communities do reflect the region's ecosystem complexities, as well as its human diversity constituted of local old settled riparian communities (cabloclos) mixed with immigrants from the north eastern Brazil. ST is a typical riparian community with the majority (93.6\%) of its population being locally born. A mix between old settled and immigrant persons occurs in the LA community. The community of NE is a typical settlement of immigrants from north eastern Brazil, with $67.7 \%$ of its population formed by immigrants, while only $32.3 \%$ of its inhabitants were born in the PA State.

The random sampling strategy is hardly applied to this area of the Amazon. Boats are the only means of transport from one village to another and villagers are spread out over large areas, which require small crafts and/or several hours of walking inland to reach ${ }^{2}$. Thus, a convenience sample was used and house-to-house sociodemographic survey was undertaken, during which the study was explained to each household, and villagers were invited to participate on a voluntary basis.

The study was conducted over two different periods, namely: i) Rainy season (RS); and ii) Dry season (DS). The inclusion criterion for the present study was being older than 18 years of age, in accordance with the study protocol that was approved by the Institutional Review Board of the University of São Paulo (File \# 043/2009) and Faculty of Health Sciences at the University of Brasília (File \# 095/08). Blood was collected following the participants informed written consent, participants were also asked to respond an interview-administered and structured questionnaire containing sociodemographic questions, as well as inquiries about lifestyle. Additionally, the subjects were weighed and measured and their BMI (weight $(\mathrm{Kg}) /($ height $(\mathrm{m}))^{2}$ ) was calculated. 


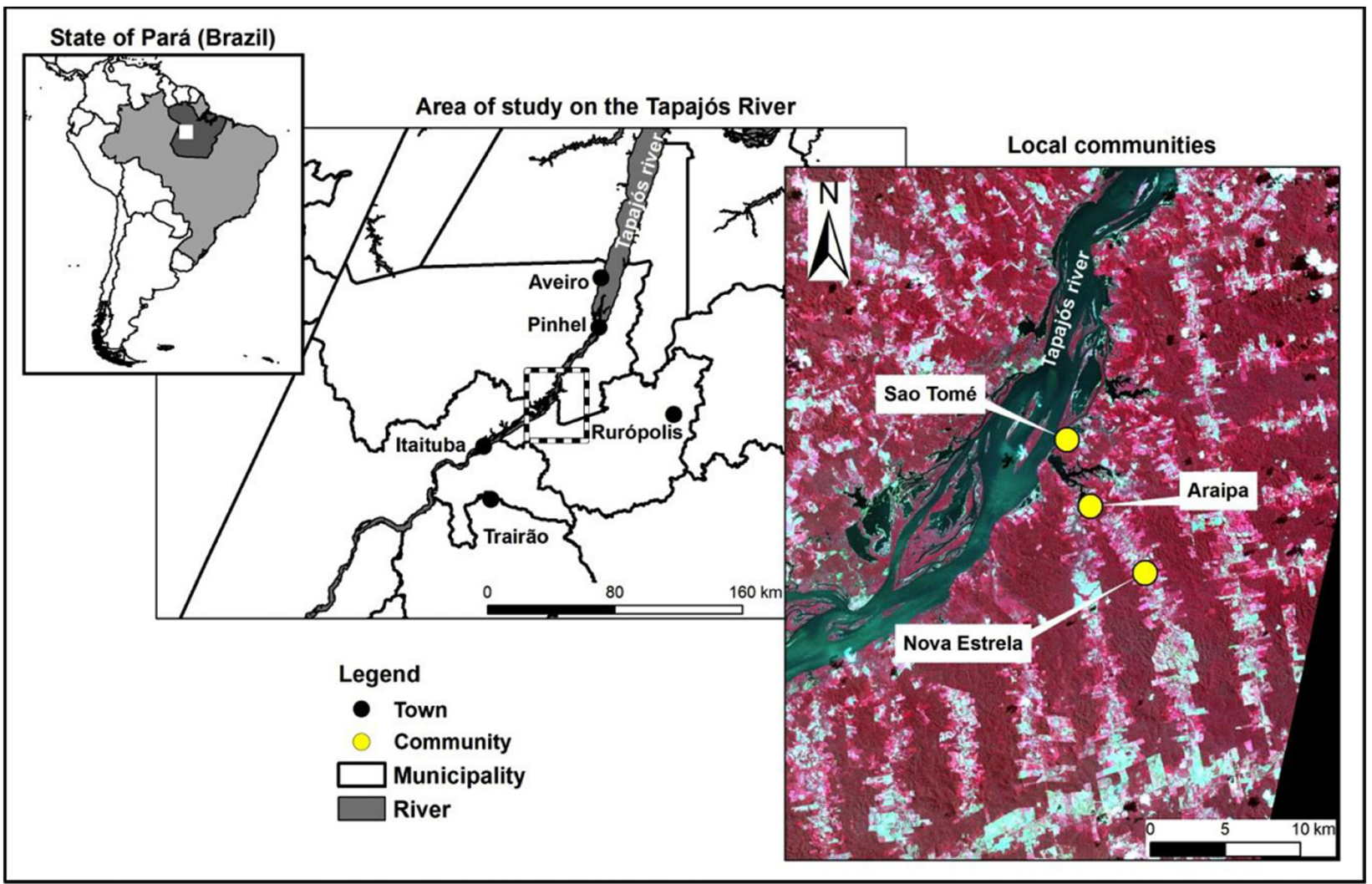

Figure 1. Localization of the three communities, São Tomé (ST), Lago Araipá (LA) and Nova Estrela (NE) in the study area (Amazonian region, Pará state, Brazil).Image graciously given by SEAS Guyane project (IRD-Cayenne) and processed by E. Delaitre (UMR ESPACE-DEV) for the PLUPH-project

\section{Blood collection}

A nurse collected a blood sample from each participant. EDTA anticoagulant and trace metal-free were used, both types of tubes being from BD Vacutainer . After collection, blood samples used for carotenoid and vitamin measurements were centrifuged. The entire blood samples were immediately frozen at $-20{ }^{\circ} \mathrm{C}$. Frozen blood/plasma samples were then immediately sent to the University of São Paulo and stored at $-80^{\circ} \mathrm{C}$ until analysis.

\section{Analyses of plasma carotenoids and vitamins}

The quantification of plasma $\beta$-carotene, lycopene and vitamins ( $\mathrm{A}$ and $\mathrm{E}$ ) was in accordance with detailed procedures previously published ${ }^{17}$.

\section{Whole blood metal determination}

The quantification of trace elements in whole blood was performed according to the appropriate method ${ }^{16}$.

\section{Statistical analyses}

Descriptive statistical analysis was used to characterize the study population. A normality test was conducted by using the Shapiro-Wilk test, and since blood micronutrients were not normally distributed, comparisons between groups (seasonality - dry and rainy season -, sex, smoking status, immigrant status, occupations alone or differently grouped, and alcohol consumption) were achieved by Mann-Whitney U- test. Additionally; Kruskal-Wallis test was used to compare inter-communities variations and age categories. The results were considered statistically significant at $\mathrm{p}<0.05$. Spearman correlation analyses were performed to evaluate associations between continuous variables. Analyses were performed using SPSS version 18.0.

\section{RESULTS}

The study population sociodemographic characteristics are shown in Table 1. The number of participants was 84 and 103 individuals in RS and DS, respectively, although only 30 persons participated in the study on both seasons. Gender distribution was similar during DS, while for RS women's participation was $20.4 \%(n=51)$ higher than men's $(n=33)$. The age distributions are also presented in Table 1.

The participants BMI was similar in both seasons (Table 1), and this parameter was not different between women and men, regardless of the season. Based on the criteria proposed by the World Health Organization (WHO) $)^{18}, 24.4 \%$ and $20.4 \%$ of the 
population was overweight, respectively during RS and DS, with BMI values varying between 25 and $30 \mathrm{Kg} / \mathrm{m}^{2}$, while $6.1 \%$ and $5.8 \%$ were considered obese $\left(\mathrm{BM} \mathrm{I}>30 \mathrm{Kg} / \mathrm{m}^{2}\right)$. Despite this, the majority of the population $(69.5 \%$ and $69.8 \%$ in RS and DS, respectively) remained within the normal range for BMI values (from 18.5 to $24.9 \mathrm{Kg} / \mathrm{m}^{2}$ ). None of the participants had BMI values $<18.5 \mathrm{Kg} / \mathrm{m}^{2}$.

Less than a third of participants were smokers and the numbers were similar for both seasons. Few individuals declared alcohol consumption in either season (Table 1). In both seasons, around $50 \%$ of participants were originally from the state of $\mathrm{PA}$, while the others came from different Brazilian regions, mainly from the Northeast. The NE community accounted for the highest number of immigrant participants: $55 \%$ and $70 \%$ of total subjects in the RS and DS, respectively (data not shown).

The majority of individuals had completed or was enrolled in elementary school or high school, and a large number of individuals had no formal education. Only two individuals in the RS and one in the DS had attended university (Table 1). Participants of this study reported a variety of occupations in their daily lives for both seasons, many of them having more than one occupation simultaneously, including fishing, farming, domestic work, teaching, boatmen, health work, commerce and regular school attendance (data not shown).

Literature data of essential metals like copper $(\mathrm{Cu})$, manganese $(\mathrm{Mn})$, selenium $(\mathrm{Se})$ and zinc $(\mathrm{Zn})^{3,14,16,19-23}$ in blood, $\beta$-carotene, lycopene and vitamins (A and $\mathrm{E}$ ) in plasma ${ }^{17,24,25}$ are shown in Table 2, along with interseasonal comparisons of these parameters. Blood $\mathrm{Cu}$, Se and $\mathrm{Zn}$ levels were significantly lower in the RS when compared to DS, whereas blood Mn levels did not differ significantly between seasons. Plasma $\beta$-carotene and vitamin E levels were significantly higher in the RS, while lycopene values were significantly lower in the RS. Seasonality did not influence plasma vitamin A values.

A comparison of our data with reference values for these nutrients shows that $22.6 \%$ of our study population had blood $\mathrm{Cu}<700 \mu \mathrm{g} / \mathrm{L}$ (hypocupremic) ${ }^{19}$ during the RS. Of these, fourteen were women (mean: $627 \pm 53 \mu \mathrm{g} / \mathrm{L}$ ) and five were men (mean: $661 \mu \mathrm{g} / \mathrm{L} \pm 25)$. In the same season, $98.8 \%$ of participants had blood $\mathrm{Mn}$ above the reference values $(>15 \mu \mathrm{g} / \mathrm{L})^{21}$, whereas

Table 1. Sociodemographic characteristics of the study population

\begin{tabular}{|c|c|c|c|c|c|c|}
\hline \multirow{2}{*}{ Variables } & \multicolumn{3}{|c|}{ Rainy Season $(n=84)$} & \multicolumn{3}{|c|}{ Dry Season $(n=103)$} \\
\hline & Mean \pm SD & Median & Range & Mean \pm SD & Median & Range \\
\hline Age (years) & $35.2 \pm 15.0$ & 32.0 & $14.0-67.0$ & $39.0 \pm 15.6$ & 38.0 & $14.0-77.0$ \\
\hline $\mathrm{BMI}\left(\mathrm{Kg} / \mathrm{m}^{2}\right)$ & $23.6 \pm 3.6$ & 23.1 & $19.2-35.2$ & $23.7 \pm 3.8$ & 23.1 & $18.7-42.3$ \\
\hline $\begin{array}{l}\text { Schooling (years } \\
\text { of education) }\end{array}$ & $4.6 \pm 3.2$ & 4.0 & $0.0-16.0$ & $3.8 \pm 3.4$ & 3.0 & $0.0-16.0$ \\
\hline \multirow[t]{7}{*}{ Age categories } & \multicolumn{4}{|c|}{$\mathrm{n}(\%)$} & \multicolumn{2}{|c|}{$\mathrm{n}(\%)$} \\
\hline & $\leq 24$ & \multicolumn{2}{|c|}{$24(28.6)$} & & \multicolumn{2}{|c|}{$21(20.4)$} \\
\hline & $25-34$ & \multicolumn{2}{|c|}{$21(25.0)$} & & \multicolumn{2}{|c|}{$23(22.3)$} \\
\hline & $35-44$ & \multicolumn{2}{|c|}{$13(15.5)$} & & \multicolumn{2}{|c|}{$21(20.4)$} \\
\hline & $45-54$ & \multicolumn{2}{|c|}{$13(15.5)$} & & \multicolumn{2}{|c|}{$18(17.5)$} \\
\hline & $55-64$ & \multicolumn{2}{|c|}{$12(14.2)$} & & \multicolumn{2}{|c|}{$12(11.6)$} \\
\hline & $\geq 65$ & \multicolumn{2}{|c|}{$01(1.20)$} & & \multicolumn{2}{|c|}{$08(7.80)$} \\
\hline
\end{tabular}

\begin{tabular}{|c|c|c|c|c|c|c|}
\hline \multicolumn{7}{|c|}{ Born in Pará State } \\
\hline & \multirow{2}{*}{$\begin{array}{l}\text { Yes } \\
\text { No }\end{array}$} & \multicolumn{2}{|c|}{$44(51.2)$} & & \multicolumn{2}{|c|}{$53(51.5)$} \\
\hline & & \multicolumn{2}{|c|}{$40(48.8)$} & & & \\
\hline \multirow[t]{3}{*}{$\begin{array}{l}\text { Alcohol } \\
\text { consumption }\end{array}$} & & & & & \multicolumn{2}{|c|}{$50(48.5)$} \\
\hline & Drinkers & \multicolumn{2}{|c|}{$14(17.0)$} & & \multicolumn{2}{|c|}{$18(17.5)$} \\
\hline & Non-drinkers & \multicolumn{2}{|c|}{$70(83.0)$} & & \multicolumn{2}{|c|}{$85(82.5)$} \\
\hline \multicolumn{7}{|c|}{ Smoking Habits } \\
\hline & Current smoker & \multicolumn{2}{|c|}{$25(29.7)$} & & \multicolumn{2}{|c|}{$32(31.1)$} \\
\hline & $\begin{array}{c}\text { Non- or } \\
\text { ex-smoker }\end{array}$ & \multicolumn{2}{|c|}{$59(70.3)$} & & \multicolumn{2}{|c|}{$71(68.9)$} \\
\hline \multicolumn{7}{|l|}{ Schooling } \\
\hline & NFE & ES or HS & $\mathrm{U}$ & NFE & ES or HS & $\mathrm{U}$ \\
\hline & $6(7.1)$ & $76(90.5)$ & $2(2.4)$ & $18(17.5)$ & $84(81.5)$ & $1(1.0)$ \\
\hline
\end{tabular}

Source: Tapajós River region, State of Pará (Brazilian Amazon), 2010-2011. SD: standard deviation; BMI: Body Mass Index; NFE: non-formal education; ES or HS: elementary (9 years) or high school (12 years) completed or enrolled; U: attended university 
Table 2. Descriptive statistics for essential metals, carotenoids and vitamins during the RS and DS

\begin{tabular}{|c|c|c|c|c|c|c|c|c|}
\hline & \multicolumn{2}{|c|}{ Rainy Season $(n=84)$} & \multicolumn{2}{|c|}{ Dry Season $(n=103)$} & \multirow{2}{*}{$\begin{array}{c}\text { Mann } \\
\text { Whitney }\end{array}$} & \multicolumn{3}{|c|}{ Literature data } \\
\hline & Median & Range & Median & Range & & Range & $\begin{array}{c}\text { Literature } \\
\text { Ranges } \\
\text { for Brazil }\end{array}$ & $\begin{array}{c}\text { Literature } \\
\text { Ranges } \\
\text { for Pará State }\end{array}$ \\
\hline $\mathrm{Cu}$ & 791 & $529-1391$ & 939 & $348-2314$ & $<0.05$ & $800-1100^{19}$ & $\begin{array}{l}620-2190^{20} \\
712-1732^{16}\end{array}$ & $\begin{array}{c}794-1631^{16} \\
495-1578 \\
(920)^{3}\end{array}$ \\
\hline $\mathrm{Mn}$ & 24 & $13-47$ & 22 & $7-60$ & NS & $4-15^{21}$ & $\begin{array}{c}6.9-10.8^{16} \\
1.9-119 \\
(14.5)^{22} \\
\end{array}$ & $9.1-18.4^{16}$ \\
\hline $\mathrm{Se}$ & 261 & $92-961$ & 344 & $93-1033$ & $<0.05$ & $100-340^{23}$ & $\begin{array}{l}49-410^{20} \\
72-158^{16}\end{array}$ & $\begin{array}{c}132-245^{16} \\
142.1-2029 \\
(361.7)^{14}\end{array}$ \\
\hline $\mathrm{Zn}$ & 7631 & $5015-13452$ & 10852 & 1294-19238 & $<0.05$ & $3500-9500^{15}$ & $470-1850^{20}$ & $\begin{array}{c}3518-12294 \\
(8945)^{3}\end{array}$ \\
\hline Carot & 1.14 & $0.25-5.53$ & 0.36 & $0.10-1.57$ & $<0.05$ & $>0.30^{24}$ & $\begin{array}{l}(0.52)^{17} \\
(0.64)^{25}\end{array}$ & - \\
\hline Lyc & 0.10 & $0.04-0.36$ & 0.23 & $0.05-0.90$ & $<0.05$ & $>0.10^{24}$ & $\begin{array}{l}(0.68)^{17} \\
(0.64)^{25}\end{array}$ & - \\
\hline Vit A & 1.90 & $1.18-2.98$ & 1.89 & $0.64-3.23$ & NS & $>0.70^{24}$ & $(2.30)^{17}$ & - \\
\hline Vit E & 20.14 & $9.45-43.2$ & 12.00 & $4.02 \pm 21.94$ & $<0.05$ & $>12.0^{24}$ & $\begin{array}{l}(25.6)^{17} \\
(29.6)^{25}\end{array}$ & - \\
\hline
\end{tabular}

Source: Tapajós River region, State of Pará (Brazilian Amazon), 2010-2011. Cu: cooper; Mn: manganese; Se: selenium; Zn: zinc; Carot: $\beta$-carotene; Lyc: Lycopene; Vit A: vitamin A; Vit E: vitamin E; p: significant when $<0.05$; NS: non-significant. The blood essential metals $(\mathrm{Cu}, \mathrm{Mn}, \mathrm{Se}$ and $\mathrm{Zn})$ are expressed in $\mu \mathrm{g} / \mathrm{L}$ while the Carotenoids ( $\beta$-carotene and Lycopene) and Vitamins (A and $\mathrm{E}$ ) are expressed in $\mu \mathrm{M} / \mathrm{L}$

Se levels $<100 \mu \mathrm{g} / \mathrm{L}$ (Se deficiency), from 100 to $340 \mu \mathrm{g} / \mathrm{L}$ (Se normal range) and from 341 to $1000 \mu \mathrm{g} / \mathrm{L}$ (superior to the normal range, but ranging without NOAEL) $)^{23}$ were found for $1.2 \%, 67.1 \%$ and $31.7 \%$ of participants, respectively. None of the participants had blood Se levels $>1000 \mu \mathrm{g} / \mathrm{L}$ (over the NOAEL established at $1000 \mu \mathrm{g} / \mathrm{L})^{23}$. Moreover, in the RS $80.3 \%$ and $19.7 \%$ of participants had blood $\mathrm{Zn}$ levels ranging from 3500 to $9500 \mu \mathrm{g} / \mathrm{L}$ and $>9500 \mu \mathrm{g} / \mathrm{L}$, respectively. None of the participants had blood $\mathrm{Zn}<3500 \mu \mathrm{g} / \mathrm{L}$. Still on RS, only one participant (1.2\%) had plasma $\beta$-carotene values $<0.30 \mu \mathrm{M} / \mathrm{L}$ (deficiency) ${ }^{24}$, while $46.6 \%$ of participants had plasma lycopene levels $<0.10 \mu \mathrm{M} / \mathrm{L}$ (deficiency) ${ }^{24}$. All participants had plasma vitamin $\mathrm{A}>0.70 \mu \mathrm{M} / \mathrm{L}$ (normal values) ${ }^{24}$, and plasma vitamin $\mathrm{E}$ of two participants was $<12 \mu \mathrm{M} / \mathrm{L}$ (deficiency) ${ }^{24}$.

A different profile was observed for $\mathrm{Cu}$, carotenoid and vitamin E blood levelsduring DS. Blood Cu levels $<700 \mu \mathrm{g} / \mathrm{L}$ were observed in $9.7 \%$ of participants, of whom five were women (mean: $610 \pm 133 \mu \mathrm{g} / \mathrm{L}$ ) and five were men (mean: $493 \pm 127 \mu \mathrm{g} / \mathrm{L}$ ). In this season, $32 \%$ of participants had plasma $\beta$-carotene values $<0.30 \mu \mathrm{M} / \mathrm{L}$ and $6 \%$ had plasma lycopene levels $<0.10 \mu \mathrm{M} / \mathrm{L}$. For $45.6 \%$ of the study population plasma concentrations of vitamin $\mathrm{E}$ were $<12 \mu \mathrm{M} / \mathrm{L}$.

For both seasons participants with blood Cu levels $<700 \mu \mathrm{g} / \mathrm{L}$ (hypocupremic) had blood $\mathrm{Zn}$ levels higher than individuals with blood Cu levels $\geq 700 \mu \mathrm{g} / \mathrm{L}$ (normocupremic). In the RS, mean blood $\mathrm{Zn}$ levels in hypocupremic participants versus normocupremic participants were $8308 \pm 1972 \mu \mathrm{g} / \mathrm{L}$ as against $6756 \pm 940 \mu \mathrm{g} / \mathrm{L}$ ( $\mathrm{p}=0.007$ ), respectively. In the DS, mean blood $\mathrm{Zn}$ levels in hypocupremic and normocupremic subjects were $11083 \pm 3571 \mu \mathrm{g} / \mathrm{L}$ and $6949 \pm 1916 \mu \mathrm{g} / \mathrm{L}(\mathrm{p}=0.0004)$, respectively.

Blood metals with respect to such categorical variables are described in Table 3. Cu and Mn mean values did not significantly vary according to any of these variables. Only during DS smokers had significantly higher blood Se than non-smokers $(\mathrm{p}=0.02)$. For $\mathrm{Zn}$ levels, in the RS blood $\mathrm{Zn}$ was significantly higher in men than women $(p=0.04)$. However, both blood Se and $\mathrm{Zn}$ did not change in accordance with alcohol consumption and immigrant status. Additionally, regarding occupation, the individuals who both farmed and fished showed significantly higher blood $\mathrm{Cu}$ than individuals with a single occupation during DS $(966 \mu \mathrm{g} / \mathrm{L} \pm 104$ versus. $947 \mu \mathrm{g} / \mathrm{L} \pm 249 ; \mathrm{p}=0.04)$; indeed, the blood $\mathrm{Mn}$, Se and $\mathrm{Zn}$ mean values did not alter regarding occupation (results not shown). Also, in both seasons none of the metals presented significant difference among age categories ( $\leq 24 ; 25-34 ; 35-44 ; 45-54 ; 55-64$ and $\geq 65$ years old $)$.

Table 3 also shows intercommunity differences for metals within the same season as well as intercommunity differences between the seasons. Increased blood $\mathrm{Cu}, \mathrm{Se}$ and $\mathrm{Zn}$ levels in the DS were observed for all communities $(\mathrm{p}<0.05)$ when compared to values found during the RS, with a more pronounced increase in blood Se observed for NE community; regardless of season, the levels of blood Se were higher in this community than LA 
Table 3. Essential metal status according to sex, smoking status, alcohol consumption, the regional origin and community location

\begin{tabular}{|c|c|c|c|c|c|c|}
\hline & \multicolumn{3}{|c|}{$R S(n=84)$} & \multicolumn{3}{|c|}{$D S(n=103)$} \\
\hline & Women $(n=51)$ & & $\operatorname{Men}(n=33)$ & Women $(n=51)$ & & $\operatorname{Men}(n=33)$ \\
\hline $\mathrm{Cu}$ & $828 \pm 199$ & & $819 \pm 117$ & $958 \pm 263$ & & $944 \pm 223$ \\
\hline Mn & $26 \pm 7$ & & $24 \pm 7$ & $26 \pm 10$ & & $23 \pm 10$ \\
\hline $\mathrm{Se}$ & $317 \pm 185$ & & $319 \pm 120$ & $411 \pm 188$ & & $384 \pm 176$ \\
\hline \multirow[t]{2}{*}{$\mathrm{Zn}$} & $7660 \pm 1934^{\star}$ & & $8430 \pm 1912$ & $10561 \pm 3559$ & & $10693 \pm 3790$ \\
\hline & Smokers $(n=25)$ & Non & -Smokers $(n=59)$ & Smokers $(n=32)$ & Non & -Smokers $(n=71)$ \\
\hline $\mathrm{Cu}$ & $795 \pm 148$ & & $837 \pm 179$ & $948 \pm 141$ & & $952 \pm 277$ \\
\hline $\mathrm{Mn}$ & $22 \pm 7$ & & $26 \pm 7$ & $24 \pm 10$ & & $24 \pm 11$ \\
\hline $\mathrm{Se}$ & $293 \pm 121$ & & $329 \pm 177$ & $444 \pm 184^{*}$ & & $374 \pm 177$ \\
\hline \multirow[t]{2}{*}{$\mathrm{Zn}$} & $7850 \pm 1787$ & & $8015 \pm 2033$ & $11126 \pm 3088$ & & $10405 \pm 3890$ \\
\hline & Drinkers $(n=14)$ & Nor & -drinkers $(n=70)$ & Drinkers $(n=18)$ & Non & -drinkers $(n=85)$ \\
\hline $\mathrm{Cu}$ & $828 \pm 199$ & & $819 \pm 117$ & $958 \pm 263$ & & $944 \pm 223$ \\
\hline $\mathrm{Mn}$ & $26 \pm 7$ & & $24 \pm 7$ & $26 \pm 10$ & & $23 \pm 10$ \\
\hline $\mathrm{Se}$ & $317 \pm 185$ & & $319 \pm 120$ & $411 \pm 188$ & & $384 \pm 176$ \\
\hline \multirow[t]{3}{*}{$\mathrm{Zn}$} & $7660 \pm 1934$ & & $8430 \pm 1912$ & $10561 \pm 3559$ & & $10693 \pm 3790$ \\
\hline & \multicolumn{3}{|c|}{ Born in Pará State } & \multicolumn{3}{|c|}{ Born in Pará State } \\
\hline & Yes $(n=55)$ & & No $(n=29)$ & Yes $(n=60)$ & & No $(n=43)$ \\
\hline $\mathrm{Cu}$ & $845 \pm 188$ & & $789 \pm 123$ & $992 \pm 272$ & & $893 \pm 182$ \\
\hline $\mathrm{Mn}$ & $26 \pm 7$ & & $24 \pm 8$ & $25 \pm 10$ & & $23 \pm 10$ \\
\hline $\mathrm{Se}$ & $332 \pm 185$ & & $290 \pm 101$ & $384 \pm 177$ & & $415 \pm 189$ \\
\hline \multirow[t]{2}{*}{$\mathrm{Zn}$} & $8034 \pm 1936$ & & $7833 \pm 2007$ & $10770 \pm 3860$ & & $10433 \pm 3401$ \\
\hline & LA $(n=36)$ & $\mathrm{NE}(n=21)$ & ST $(n=27)$ & LA $(n=44)$ & $\mathrm{NE}(\mathrm{n}=30)$ & ST $(n=29)$ \\
\hline $\mathrm{Cu}$ & $854 \pm 172$ & $797 \pm 134$ & $807 \pm 193$ & $950 \pm 216^{a}$ & $917 \pm 165^{a}$ & $988 \pm 335^{\mathrm{a}}$ \\
\hline $\mathrm{Mn}$ & $25 \pm 7$ & $25 \pm 8$ & $25 \pm 8$ & $22 \pm 9^{a}$ & $26 \pm 12$ & $25 \pm 10$ \\
\hline $\mathrm{Se}$ & $305 \pm 158$ & $380 \pm 198^{+}$ & $285 \pm 123$ & $325 \pm 124^{\mathrm{a}}$ & $546 \pm 198^{a+}$ & $348 \pm 144^{\mathrm{a}}$ \\
\hline $\mathrm{Zn}$ & $8144 \pm 2053$ & $7792 \pm 1836$ & $7867 \pm 1958$ & $9628 \pm 3280^{\mathrm{a}}$ & $11923 \pm 3237^{\mathrm{a}}$ & $10743 \pm 4255^{\mathrm{a}}$ \\
\hline
\end{tabular}

Source: Tapajós River region, State of Pará (Brazilian Amazon), 2010-2011. Cu: cooper; Mn: manganese; Se: selenium; Zn: zinc. ${ }^{\star}$ Significant difference for a given season (Mann Whitney U test). ${ }^{a}$ Significant different (Mann Whitney U test) from values found in RS for the same community. ${ }^{+}$Intercommunity significant difference (Kruskall Wallis test).

and ST ( $<<0.05)$. Moreover, blood Mn decreased significantly during DS in comparison with RS levels only in LA community $(\mathrm{p}<0.05)$.

Carotenoids and vitamin mean blood values follow changes in some sociodemographic and lifestyle determinants (Table 4). For instance, alcohol consumers had significantly lower (in both seasons) plasma $\beta$-carotene levels than non-consumers (both $\mathrm{p}<0.0001)$. Interestingly, plasma lycopene was significantly higher during DS only in subjects who were born in the State of PA when compared to individuals not born there $(\mathrm{p}<0.0001)$. Regarding occupation (data not shown), only during DS those who described themselves as both farmers and fishermen $(n=35)$ have plasma $\beta$-carotene that was significantly lower than that of single-occupation, for 41 participants $(0.23 \mu \mathrm{M} / \mathrm{L} \pm 0.16$ vs. $0.42 \mu \mathrm{M} / \mathrm{L} \pm 0.24 ; \mathrm{p}=0.01)$.

Table 4 also shows that plasma vitamin A was significantly higher in alcohol drinkers compared to non-drinkers $(\mathrm{p}=0.03)$ in both seasons. For vitamin E, their plasma levels were respectively significantly lower in drinkers and smokers compared to non-drinkers $(\mathrm{p}=0.04)$ and non-smokers $(\mathrm{p}=0.01)$ only during DS. In the same season, plasma vitamin E levels were significantly $(\mathrm{p}<0.0001)$ higher in participants born in PA. In the same way that essential metals, for both seasons, the plasma vitamins and carotenoids levels were not different among the age categories.

In all communities, plasma $\beta$-carotene levels were higher during RS in comparison to DS levels $(\mathrm{p}<0.05)$ (Table 4). Additionally, during RS the order of values for this carotenoid was $L A>S T>N E(p<0.05)$, while during DS the order of values for plasma $\beta$-carotene levels was $\mathrm{LA}>\mathrm{NE}>\mathrm{ST}(\mathrm{p}<0.05)$. In contrast to plasma $\beta$-carotene levels, all communities had lower plasma lycopene concentrations in the RS than those in the DS $(\mathrm{p}<0.05)$. RS plasma levels of this micronutrient were lower in ST than those in LA or NE $(\mathrm{p}<0.05)$. For the DS, plasma lycopene dropped in the order of $\mathrm{ST}>\mathrm{LA}>\mathrm{NE}(\mathrm{p}<0.05)$. Regarding vitamins, neither vitamin A nor vitamin E plasma levels varied among communities in either season. In addition, all communities presented higher plasma vitamin E levels during RS regarding DS $(\mathrm{p}<0.05)$.

Additionally, in both seasons, none of the continuous variables like age, BMI or years of education were associated with blood metals levels, carotenoids and vitamins (data not shown). 
Table 4. Plasma carotenoids and vitamins according to sex, smoking status, alcohol consumption, regional origin and community location

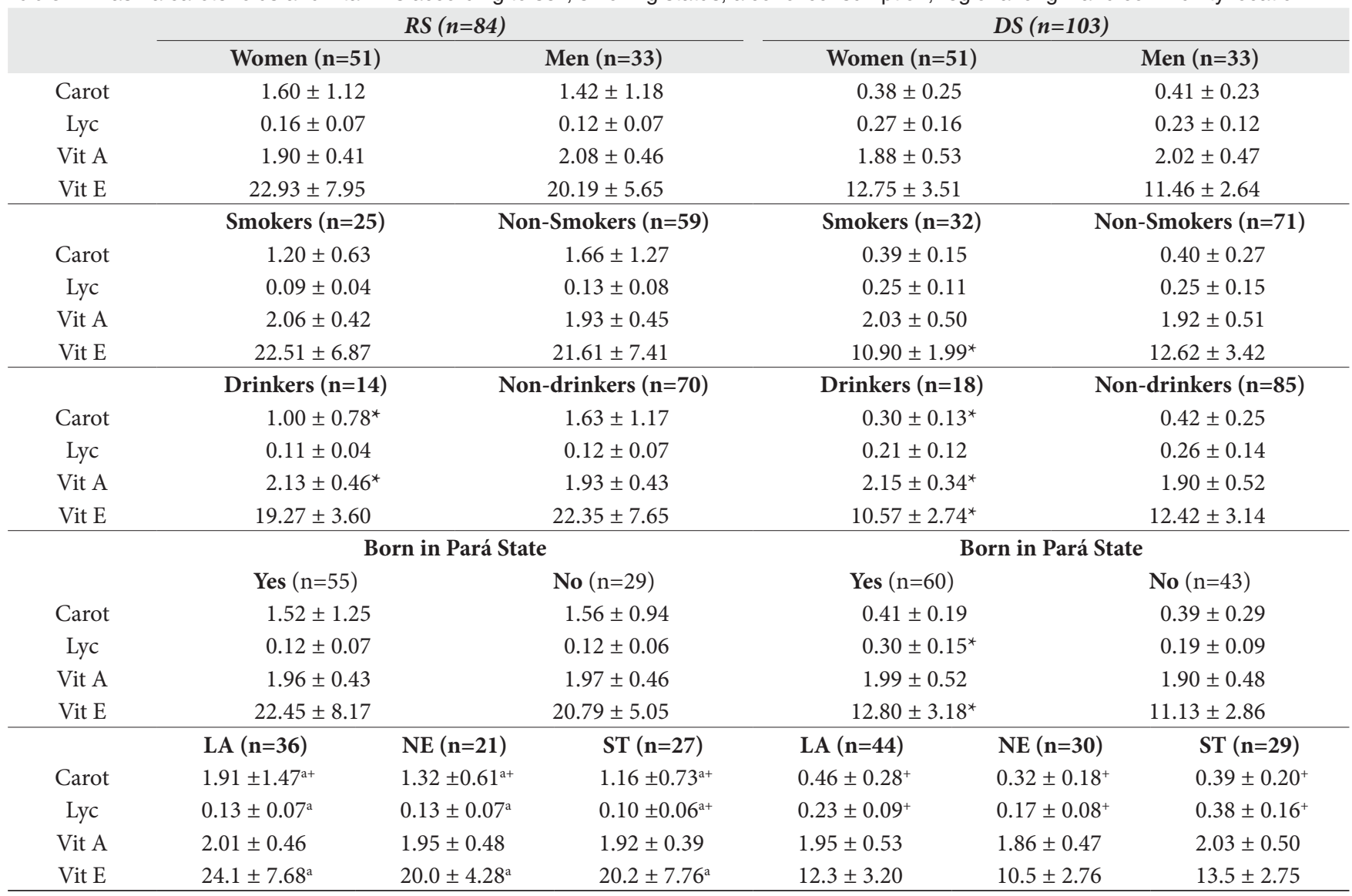

Source: Tapajós River region, State of Pará (Brazilian Amazon), 2010-2011. Carot: $\beta$-carotene; Lyc: lycopene; Vit A: vitamin A; Vit E: vitamin E. ${ }^{*}$ Significant difference for a given season (Mann Whitney U test). ${ }^{a}$ Significant different (Mann Whitney U test) from values found in RS for the same community. ${ }^{+}$Intercommunity significant difference (Kruskall Wallis test).

\section{DISCUSSION}

To our knowledge, this is the first study to provide plasmatic levels of lycopene, $\beta$-carotene and vitamins (A and $\mathrm{E}$ ) in riparian populations of the Brazilian Amazon. The results also demonstrate that seasonality appears to influence blood micronutrient levels in agricultural and fishing villagers of the Tapajós River region. Community location, sex, smoking status and drinking habits as well as regional origin did also alter some blood micronutrient levels.

Knowledge about blood micronutrient levels is of great importance in Brazilian Amazon, since many publications have shown that several nutrients modify the toxicokinetics and toxicodynamics of $\mathrm{Hg}^{2,9,10,26,27}$, which is particularly interesting in the context of this current investigation since numerous studies have reported high $\mathrm{Hg}$ levels in hair, blood and plasma among Amazonian populations ${ }^{5-7}$. Our findings of seasonal blood variation of essential metals ( $\mathrm{Cu}$, Se and $\mathrm{Zn}$ ), carotenoids and vitamin $\mathrm{E}$ are probably a result of seasonal variations in food availability. For example, bean consumption by this population decreases significantly during DS and beans are an important source of $\mathrm{Cu}$ and $\mathrm{Zn}^{28}$. This may be one determinant to lower blood levels of $\mathrm{Cu}$ and $\mathrm{Zn}$ during DS. In addition, regardless of the season, our findings indicate that sources of both $\mathrm{Zn}$ and $\mathrm{Cu}$ appear to be uniform in LA, NE and ST communities.

In both seasons the average values for blood $\mathrm{Cu}$ are consistent with previous studies carried out with other communities near the study region ${ }^{3}$, as well as communities located in other Brazilian regions ${ }^{16}$, or in other populations elsewhere ${ }^{15,29,30}$. Although hypocupremia is a rare condition in humans, it has been observed in the present study population (mainly during the RS). It is known that an increase in $\mathrm{Zn}$ intake may stimulate the synthesis of metalothionein, which has a high affinity for $\mathrm{Cu}$. This probably results in a decrease in $\mathrm{Cu}$ absorption by intestinal cells ${ }^{31}$ and may contribute to the observed hypocupremia, since individuals with blood $\mathrm{Cu}<700 \mu \mathrm{g} / \mathrm{L}$ had higher blood $\mathrm{Zn}$.

While the reference range in other biomonitoring studies for blood $\mathrm{Zn}$ lies from $3900 \mu \mathrm{g} / \mathrm{L}$ to $9102 \mu \mathrm{g} / \mathrm{L}^{15,30}$, much higher ranges

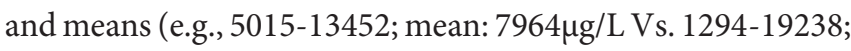
mean: $10646 \mu \mathrm{g} / \mathrm{L}$ ) in RS and DS, respectively, were observed in our study population, which could be explained by the high levels of $\mathrm{Zn}$ in the typical diet of these riparian population $\mathrm{s}^{28}$. In the same way, independently of the season, the Mn levels 
are greater than those described for reference range ${ }^{21}$ and in other Brazilian regions ${ }^{16,20}$. However this study confirms that populations from Northern Brazil have significantly higher Mn levels in comparison to people from other Brazilian states ${ }^{16,22}$. Açai fruit, a typical Amazon region berry, has high levels of essential elements, especially $\mathrm{Mn}^{32}$, and its consumption could be associated with high blood Mn levels. However, the interpretation of our findings with respect to such status is limited by the lack of information on individuals' diet (for example, nutrients quantification in food more consumed by our study population).

In addition to the increased zinc levels, typical riparian foods including Brazil nuts, fish, eggs and chicken, are known sources of $\mathrm{Se}^{14}$, which may explain the higher levels of blood Se found in this population as compared to other geographic regions in Brazil ${ }^{16}$ and other countries ${ }^{15,31}$; usually the observed blood levels are lower than $120 \mu \mathrm{g} / \mathrm{L}^{23}$ in populations that do not ingest Se pills. Se concentrations in the same type of food vary from community to community and from season to season in this area ${ }^{12}$, and this could explain our findings that in the study population the DS blood Se levels were higher than RS levels, which differ from Lemire et al. (2009)'s finding ${ }^{33}$. These authors found that riparians living close to the area evaluated in the present study had more pronounced blood Se levels, but not so significant in the rising water season. However, the same authors found that when only inhabitants of the same community were considered, blood Se levels were higher in the DS. The higher blood Se levels in NE compared to other communities (Table 4) confirm intercommunity variation and show that availability of Se-rich food and consumption habits differ among communities ${ }^{14,33}$.

Interestingly, the population's RS plasma $\beta$-carotene levels are substantially higher than those currently found in other populations ${ }^{13,34}$, and even in other Brazilian areas ${ }^{17,25}$. During the dry season, plasma $\beta$-carotene levels drop considerably but still remain in the safe range $(>0.30 \mu \mathrm{M} / \mathrm{L})$ recommended by $\mathrm{WHO}^{24}$. It is known that the main sources of $\beta$-carotene are fruits and vegetables, and a previous study conducted in the same region revealed that the consumption of this type of food is much higher in the RS when compared to the DS ${ }^{1}$, which is consistent with the interseasonal pattern we found. Unlike those of plasma $\beta$-carotene, the levels of lycopene were higher in the DS, with mean levels found in both seasons lower than in other studies with other populations all over the world ${ }^{34,35}$, and even from studies with other Brazilians living in the southern region $^{17,25}$. Plasma carotenoids levels found in this study are in good agreement with the lower limit found for North American populations ${ }^{35}$.

WHO defines plasma vitamin A deficiency as $<0.35 \mu \mathrm{M} / \mathrm{L}$, with incipient deficiency levels ranging from 0.35 to $0.70 \mu \mathrm{M} / \mathrm{L}^{24}$. We observed that regardless of season, plasma vitamin A values were above the WHO normal, which disagrees with previous studies of Amazon populations that reported a deficiency of this vitamin ${ }^{36,37}$.

We observed vitamin E deficiency in a larger number of people during the DS, assuming the WHO definition of vitamin E deficiency as plasma values $<12 \mu \mathrm{M} / \mathrm{L}^{24}$. Fish is the route of exposure to $\mathrm{Hg}$ for this study population ${ }^{38}$, but fish also contains important nutrients such as proteins, omega- 3 fatty acids and vitamin $\mathrm{E}^{39}$. The amount of fish consumed in this region does not differ between DS and RS, albeit the consumed fish species vary along with seasons ${ }^{1,2}$. Thus, since plasma vitamin $\mathrm{E}$ was different between seasons, we hypothesise that vitamin E levels may depend upon fish species being consumed. Additionally, our findings show similar plasma vitamin E levels in the three communities (all deficient during DS), which may indicate a common vitamin E source, independent of the location but seems to be dependent on seasonality.

Several studies evaluate the influence of sociodemographic variables on blood micronutrient levels. The relationship between blood $\mathrm{Cu}$ and $\mathrm{Zn}$ levels and age is contradictory in the literature ${ }^{3,15,16}$. In the present study, the lack of correlation between age and blood $\mathrm{Cu}$ and $\mathrm{Zn}$ levels may be explained by the youth of most participants. Moreover, contrary to other studies, age does not influence blood $\mathrm{Mn}$ and Se levels or plasma vitamins $\mathrm{A}$ or $\mathrm{E}^{14,15,40}$. Among carotenoids, $\beta$-carotene is generally higher in individual's $\geq 60$ years, while lycopene is lower in individual's $\geq 60$ years $^{41}$.

The association of micronutrients with age and sex is heavily dependent upon the presence of covariates associated to lifestyle. Inflammatory processes, oxidative stress and possible reduction in food intake in smokers may elevate $\mathrm{Cu}$ status ${ }^{42}$, as well as decrease Se, $\beta$-carotene and lycopene blood levels ${ }^{43}$. Decreased bioavailability of vitamin $A$ and $\beta$-carotene is also reported in smokers ${ }^{42}$. However, previous studies have found no blood variability of $\mathrm{Cu}, \mathrm{Mn}, \mathrm{Zn}, \beta$-carotene, lycopene or vitamin $\mathrm{A}^{13,15,40}$ regarding smoking status. Following Sanchez and colleagues ${ }^{40}$, we hypothesise that different quantities of cigarettes smoked may be reflected in different conclusions in the literature. Unfortunately, the investigation of the number of cigarettes smoked per day and the dosage of cotinine were not performed in the present study.

Alcoholic beverages consumption leads to dysfunctions in the neuroendocrine system, and can reduce $\mathrm{Cu}^{44}$ and $\mathrm{Se}^{45}$ blood levels and/or increase $\mathrm{Mn}$ concentration in this biological compartment ${ }^{46}$. Moreover, an increase in $\mathrm{Zn}$ renal excretion could be associated with alcohol consumption ${ }^{47}$, while the consumption of grape-based alcoholic beverage, such as wine, can induce additional $\mathrm{Cu}^{15}$ and $\mathrm{Zn}^{48}$ intake. Alcohol consumption was not associated with the concentration of blood essential elements evaluated in the present investigation, the same being 
observed with other populations ${ }^{15,49}$. It is worth pointing out that the majority of the participants in the present study declared they do not drink alcoholic beverages, and the small number of alcohol consumers may have contributed to our findings. On the other hand, even with the small number of alcohol drinkers, alcohol was an important covariate for the changes in $\beta$-carotene and vitamins $\mathrm{A}$ and $\mathrm{E}$ levels.

In this current study blood $\mathrm{Cu}$ levels rose in participants who both farmed and fished, and in these same individuals $\beta$-carotene levels were lower. These findings may be associated to the amount of physical exercise performed by fishermen and farmers since it has been found that physical activity can result in the redistribution of micronutrients in the body ${ }^{50}$. In the Amazon region, performing agricultural and fishing activities requires intense physical effort, particularly so during the DS. Moreover, blood $\mathrm{Cu}$ levels tend to increase with intense physical activity ${ }^{42}$ while plasma $\beta$-carotene tends to move in the opposite direction ${ }^{51}$; more free radicals are produced in people doing physical exercise than in sedentary individuals, and this can cause $\beta$-carotene depletion.

Overall, our study has some limitations, one of the most important being that there was no research about the types of food consumed (through food frequency questionnaire with the study population). Thus, the information on food frequency consumed during the dry and rainy season in this study was based on a study of $2001^{1}$, which was performed in the community of Brasília Legal, nearby our study area. Another limitation is that we did not evaluate the nutrient contents of the main foods consumed in this region during the two study periods, while it is known that nutrient contents can be different among different places ${ }^{17,32}$. These limitations prevented us from identifying more specific exposure pathways to blood $\mathrm{Cu}, \mathrm{Mn}$, Se, $\mathrm{Zn}$, carotenoids and vitamins in this population.

\section{CONCLUSIONS}

This study highlights for the first time carotenoids and vitamins blood levels for Tapajós River populations. It sets baseline values in two different seasons for populations characterised with a unique lifestyle and eating habits, which change considerably according to seasons. Our data provide a basis for future studies aiming at understanding the effects of micronutrient modulation on the toxic effects of $\mathrm{Hg}$ exposure and/or lead, to which the study population is knowingly exposed.

\section{REFERENCES}

1. Passos CJS, Mergler D, Gaspar E, Morais S, Lucotte M, Larribe F, et al. Characterization of the diet of a riparian population in the Brazilian Amazon. Rev Saúde Amb. 2001;4:72-84.

2. Passos CJS, Mergler D, Fillion M, Lemire M, Mertens F, Guimarães JR, et al. Epidemiologic confirmation that fruit consumption influences mercury exposure in riparian communities in the Brazilian Amazon. Environ Res. 2007;105(2):183-93. http://dx.doi.org/10.1016/j.envres.2007.01.012. PMid:17374370.

3. Rodrigues JL, Batista BL, Fillion M, Passos CJS, Mergler D, Barbosa Jr F. Trace element levels in whole blood of riparian villagers of the Brazilian Amazon. Sci Total Environ. 2009;407(13):4168-73. http://dx.doi.org/10.1016/j. scitotenv.2009.02.041. PMid:19329141.

4. Malm O, Pfeiffer WC, Souza CMM, Reuther R. Mercury pollution due to gold mining in the Madeira river basin, Brazil. Ambio. 1990;19:11-5.

5. Dolbec J, Mergler D, Larribe F, Roulet M, Lebel J, Lucotte M. Sequential analysis of hair mercury levels in relation to fish diet of an Amazonian population, Brazil. Sci Total Environ. 2001;271(1-3):87-97. http://dx.doi. org/10.1016/S0048-9697(00)00835-4. PMid:11346043.

6. Passos CJ, Mergler D, Gaspar E, Morais S, Lucotte M, Larribe F, et al. Eating tropical fruit reduces mercury exposure from fish consumption in the Brazilian Amazon. Environ Res. 2003;93(2):123-30. http://dx.doi. org/10.1016/S0013-9351(03)00019-7. PMid:12963396.

7. Grotto D, Valentini J, Fillion M, Passos CJS, Garcia SC, Mergler D, et al. Mercury exposure and oxidative stress in communities of the Brazilian Amazon. Sci Total Environ. 2010;408(4):806-11. http://dx.doi.org/10.1016/j. scitotenv.2009.10.053. PMid:19914681.
8. Gagné D, Lauzière J, Blanchet R, Vézina $C$, Vaissière $\mathrm{E}$, Ayotte $\mathrm{P}$, et al. Consumption of tomato products is associated with lower blood mercury levels in Inuit preschool children. Food Chem Toxicol. 2013;51:404-10. http://dx.doi.org/10.1016/j.fct.2012.10.031. PMid:23127601.

9. Chapman L, Chan HM. The influence of nutrition on methyl mercury intoxication. Environ Health Perspect. 2000;108(Suppl 1):29-56. http:// dx.doi.org/10.1289/ehp.00108s129. PMid:10698722.

10. Bélanger M-C, Mirault M-E, Dewailly E, Plante M, Berthiaume L, Noël $\mathrm{M}$, et al. Seasonal mercury exposure and oxidant-antioxidant status of James Bay sport fishermen.. Metabolism. 2008;57(5):630-6. http://dx.doi. org/10.1016/j.metabol.2007.12.006. PMid:18442625.

11. Thurnham DI, Northrop-Clewes CA, Chopra M. Biomarkers of vegetable and fruit intakes. Am J Clin Nutr. 1998;68(3):756-8. PMid:9734759.

12. Lemire M, Fillion M, Barbosa F Jr, Guimarães JR, Mergler D. Elevated levels of selenium in the typical diet of Amazonian riverside populations. Sci Total Environ. 2010;408(19):4076-84. http://dx.doi.org/10.1016/j. scitotenv.2010.05.022. PMid:20646739.

13. Galan P, Viteri FE, Bertrais S, Czernichow S, Faure H, Arnaud J, et al. Serum concentrations of beta-carotene, vitamins $\mathrm{C}$ and $\mathrm{E}$, zinc and selenium are influenced by sex, age, diet, smoking status, alcohol consumption and corpulence in a general French adult population. Eur J Clin Nutr. 2005;59(10):1181-90. http://dx.doi.org/10.1038/sj.ejcn.1602230. PMid:16034362.

14. Lemire M, Mergler D, Fillion M, Passos CJ, Guimarães JR, Davidson R, et al. Elevated blood selenium levels in the Brazilian Amazon. Sci Total Environ. 2006;366(1):101-11. http://dx.doi.org/10.1016/j.scitotenv.2005.08.057. PMid:16289298. 
15. Bocca B, Madeddu R, Asara Y, Tolu P, Marchal JÁ, Forte G. Assessment of reference ranges for blood $\mathrm{Cu}, \mathrm{Mn}, \mathrm{Se}$ and $\mathrm{Zn}$ in a selected Italian population. J Trace Elem Med Biol. 2011;25(1):19-26. http://dx.doi.org/10.1016/j. jtemb.2010.12.004. PMid:21242073.

16. Nunes JA, Batista BL, Rodrigues JL, Caldas NM, Neto JÁ, Barbosa Jr F. A simple method based on ICP-MS for estimation of background levels of arsenic, cadmium, copper, manganese, nickel, lead and selenium in blood pf the brazilian population. J Toxicol Environ Health A. 2010;73(13-14):87887. http://dx.doi.org/10.1080/15287391003744807. PMid:20563921.

17. Charão MF, Moro AM, Brucker N, Bulcão RP, Baierle M, Freitas F, et al Simultaneous quantification of lycopene, $\beta$-carotene, retinol and $\alpha$-tocopherol in plasma after a simple extraction procedure: stability study and application to human volunteers. J Braz Chem Soc. 2012;23(8):1441-9. http://dx.doi. org/10.1590/S0103-50532012005000001.

18. World Health Organization. Obesity: preventing and managing the global epidemic. Geneva; 1996. Report of World Health Organization Consultation on Obesity.

19. World Health Organization. Trace elements in human nutrition and health. Geneva: WHO; 1996

20. Baierle M, Charão MF, Göethel G, Barth A, Fracasso R, Bubols G, et al. Are delta-aminolevulinate dehydratase inhibition and metal concentrations additional factors for the age-related cognitive decline? Int J Environ Res Public Health. 2014;11(10):10851-67. http://dx.doi.org/10.3390/ ijerph111010851. PMid:25329536.

21. Agency for Toxic Substances and Disease Registry. Toxicological profile for manganese. Atlanta: Centers for Disease Control; 2012.

22. Freire C, Koifman RJ, Fujimoto D, de Oliveira Souza VC, Barbosa F Jr, Koifman S. Reference values of cadmium, arsenic and manganese in blood and factors associated with exposure levels among adult population of Rio Branco, Acre, Brazil. Chemosphere. 2015;128:70-8. http://dx.doi. org/10.1016/j.chemosphere.2014.12.083. PMid:25655821.

23. United State Environmental Protection Agency. Integrated risk information systems (IRIS) for selenium. Washington: National Centre for Environmental Assessment, Office of Research and Development; 2002. 444 p.

24. World Health Organization. Obesity, preventing and managing the global epidemic. Geneva: WHO; 2000. Report of the World Health Organization Consultation of Obesity.

25. Roehrs M, Valentini J, Paniz C, Moro A, Charão M, Bulcão R, et al. The relationships between exogenous and endogenous antioxidants with the lipid profile and oxidative damage in hemodialysis patients. BMC Nephrol. 2011;12(1):59. http://dx.doi.org/10.1186/1471-2369-12-59. PMid:22029620.

26. Grotto D, Vicentini J, Angeli JPF, Latorraca EF, Monteiro PA, Barcelos GR, et al. Evaluation of protective effects of fish oil against oxidative damage in rats exposed to methylmercury. Ecotoxicol Environ Saf. 2011a;74(3):48793. http://dx.doi.org/10.1016/j.ecoenv.2010.10.012. PMid:20970192.

27. Manzolli ES, Serpeloni JM, Grotto D, Bastos JK, Antunes LMG, Barbosa F, et al. Protective effects of the flavonoid chrysin against methylmercuryinduced genotoxicity and alterations of antioxidant status, in vivo. Oxid Med Cell Longev. 2015;2015:602360. http://dx.doi.org/10.1155/2015/602360. PMid:25810809.

28. Nardi EP, Evangelista FS, Tormen L, Saint'Pierre TD, Curtius AJ, Souza SS, et al. The use of inductively coupled plasma mass spectrometry (ICPMS) for the determination of toxic and essential elements in different types of food samples. Food Chem. 2009;112(3):727-32. http://dx.doi. org/10.1016/j.foodchem.2008.06.010.
29. Minoia C, Sabbioni E, Apostoli P, Pietra R, Pozzoli L, Gallorini M, et al. Trace element reference values in tissues from inhabitants of the European community I. A study of 46 elements in urine, blood and serum of Italian subjects. Sci Total Environ. 1990;95:89-105. http://dx.doi.org/10.1016/00489697(90)90055-Y. PMid:2402627.

30. Moreno MA, Marin C, Vinagre F, Ostapczuk P. Trace element levels in whole blood samples from residents of the city Badajoz, Spain. Sci Total Environ. 1999;229(3):209-15. http://dx.doi.org/10.1016/S0048-9697(99)00074-1. PMid:10418170.

31. Bárány E, Bergdahl IA, Bratteby LE, Lundh T, Samuelson G, Schutz A, et al. Relationships between trace element concentrations in human blood and serum. Toxicol Lett. 2002;134(1-3):177-84. http://dx.doi.org/10.1016/ S0378-4274(02)00187-X. PMid:12191876.

32. Santos VS, Teixeira GHA, Barbosa Jr F. Açaí (Euterpe oleracea Mart.): a tropical fruit with high levels of essential minerals-especially manganese-and its contribution as a source of natural mineral supplementation. J Toxicol Environ Health A. 2014;77(1-3):80-9. http://dx.doi.org/10.1080/1528739 4.2014.866923. PMid:24555649.

33. Lemire M, Mergler D, Huel G, Passos CJS, Fillion M, Philibert A, et al. Biomarkers of selenium status in the Amazoniam context: blood, urine and sequential hair segments. J Expo Sci Environ Epidemiol. 2009;19(2):213-22. http://dx.doi.org/10.1038/jes.2008.14. PMid:18446187.

34. Olmedilla B, Granado F, Southon S, Wright AJ, Blanco I, Gil-Martinez $\mathrm{E}$, et al. Serum concentrations of carotenoids and vitamins $\mathrm{A}, \mathrm{E}$, and $\mathrm{C}$ in control subjects from five European countries. Br J Nutr. 2001;85(2):22738. http://dx.doi.org/10.1079/BJN2000248. PMid:11242491.

35. National Health and Nutrition Examination Survey. National report on biochemical indicators of diet and nutrition in the U.S. population 19992002. Atlanta: NHANES; 2002.

36. Alencar FH, Castro JS, Yuyama LKO, Marinho HA, Nagahama D. Diagnóstico da realidade nutricional no Estado do Amazonas, Brasil. I: Hipovitaminose A. Acta Amazon. 2002;32(4):613-23. http://dx.doi.org/10.1590/180943922002324613.

37. Pinheiro MM, Ciconelli RM, Chaves GV, Aquino L, Juzwiak CR, Genaro PS, et al. Antioxidant intake among Brazilian adults - The Brazilian Osteoporosis Study (BRAZOS): a cross-sectional study. Nutr J. 2011;10(1):39. http://dx.doi.org/10.1186/1475-2891-10-39. PMid:21513578.

38. Grotto D, Valentini J, Serpeloni JM, Monteiro PA, Latorraca EF, de Oliveira RS, et al. Evaluation of toxic effects of a diet containing fish contaminated with methylmercury in rats mimicking the exposure in the Amazon riverside population.. Environ Res. 2011b;111(8):1074-82. http://dx.doi. org/10.1016/j.envres.2011.09.013. PMid:22000760.

39. Afonso C, Lourenço HM, Pereira C, Martins MF, Carvalho ML, Castro $\mathrm{M}$, et al. Total and organic mercury,selenium and $\alpha$-tocopherol in some deep-water fish species. J Sci Food Agric. 2008;88(14):2543-50. http:// dx.doi.org/10.1002/jsfa.3379.

40. Sánchez C, López-Jurado M, Aranda P, Llopis J. Plasma levels of copper, manganese and selenium in an adult population in southern Spain: Influence of age, obesity and lifestyle factors. Sci Total Environ. 2010;408(5):1014-20. http://dx.doi.org/10.1016/j.scitotenv.2009.11.041. PMid:20018346.

41. Milne DB, Nielsen FH. Effects of a diet low in copper on copper-status indicators in postmenopausal women. Am J Clin Nutr. 1996;63(3):358-64. PMid:8602593.

42. Northrop-Clewes CA, Thurnham DI. Monitoring micronutrients in cigarette smokers. Clin Chim Acta. 2007;377(1-2):14-38. http://dx.doi. org/10.1016/j.cca.2006.08.028. PMid:17045981. 
43. Kocyigit A, Erel O, Gur S. Effects of tobacco smoking on plasma selenium, zinc, copper and iron concentrations and related antioxidative enzyme activities. Clin Biochem. 2001;34(8):629-33. http://dx.doi.org/10.1016/ S0009-9120(01)00271-5. PMid:11849622.

44. Fields M, Lewis CG. Alcohol consumption aggravates copper deficiency. Metabolism. 1990;39(6):610-3. http://dx.doi.org/10.1016/0026-0495(90)90027-A. PMid:2352478.

45. Borawska MH, Witkowska AM, Hukalowicz K, Markiewicz R. Influence of dietary habits on serum selenium concentration. Ann Nutr Metab. 2004;48(3):134-40. http://dx.doi.org/10.1159/000078375. PMid:15133317.

46. Sassine MP, Mergler D, Bowler R, Hudnell HK. Manganese accentuates adverse mental health effects associated with alcohol use disorders. Biol Psychiatry. 2002;51(11):909-21. http://dx.doi.org/10.1016/S00063223(01)01350-6. PMid:12022965.

47. King JC. Determinants of maternal zinc status during pregnancy. Am J Clin Nutr. 2000;71(5 Suppl):1334S-43S. PMid:10799411.
48. López-Artíguez M, Grilo A, Soria ML, Castro M, Repetto M. Levels of zinc, copper and lead in wines from the area south of Seville. Bull Environ Contam Toxicol. 1990;45(5):711-7. http://dx.doi.org/10.1007/BF01700990. PMid:2265270.

49. Sánchez C, López-Jurado M, Planells E, Llopis J, Aranda P. Assessment of iron and zinc intake and related biochemical parameters in an adult Mediterranean population from southern Spain: influence of lifestyle factors. J Nutr Biochem. 2009;20(2):125-31. http://dx.doi.org/10.1016/j. jnutbio.2007.12.008. PMid:18547795.

50. Nasolodin W, Gladkikh IP. Manganese provision in trained and untrained schoolchildren and students in different seasons. Gig Sanit. 2007;1(1):5961. PMid:17343058

51. Parthasarathy S, Santanam N, Ramachandran S, Meilhac O. Potential role of oxidized lipids and lipoproteins in antioxidant defense. Free Radic Res. 2000;33(3):197-215. http://dx.doi.org/10.1080/10715760000301381. PMid:10993475.

Received on: July 06, 2015 Accepted on: Sept. 09, 2015 